\title{
BLOCK LACE FROM BOBOWA AS AN EXAMPLE OF DEVELOPING DEXTERITY AND CULTIVATIN REGIONAL TRADITION
}

\section{Elżbieta MASTALERZ}

Abstract: This article describes the basics of beautiful handcraft: making block lace. The school in Bobowa cultivates tradition and help its students develop dexterity and interests during technical education lessons.

Key words: tradition, dexterity, block lace.

\section{KORONKI KLOCKOWE Z BOBOWEJ JAKO PRZYKLAD KSZTALTOWANIA ZRECZNOŚCI I KULTYWOWANIA TRADYCJI REGIONALNYCH}

Streszczenie: $W$ artykule przedstawiono podstawowe zagadnienia zwiąane z pięknym rękodzietem wytwarzaniem koronek klockowych. Szkoła w Bobowej w ramach edukacji ogólnotechnicznej kultywuje tradycje regionalne rozwijając zainteresowania uczniów, zręczność i poczucie piękna.

Słowa kluczowe: tradycje, zręczność, koronka klockowa.

\section{Wstęp}

Jednym z najważniejszych zadań współczesnej polskiej szkoły jest całościowy, harmonijny rozwój ucznia w okresie szkolnym, a także rozbudzanie uczuć patriotycznych, estetycznych, poznanie historii i tradycji regionu. Uczeń poprzez uczestnictwo w charakterystycznych dla jego miejsca zamieszkania zajęciach, nie tylko teoretycznie poznaje historię i tradycje miejscowości, regionu, kraju, ale emocjonalnie angażuje się, nabywając jednocześnie podstawy praktyczne do ewentualnej przyszłej twórczej pracy. W kontekście przeciążenia wiedzą teoretyczna uczniów współczesnej szkoły, na podkreślenie zasługują przykłady praktycznych działań łączących rozwój zręczności $\mathrm{z}$ poznawaniem historii i tradycji. Przykładem tego typu działań jest szkoła w Bobowej, miejscowości - kolebce koronkarstwa klockowego w Polsce. Dostępne teksty źródłowe potwierdzają fakt, że na dziesiątki lat przed założeniem w 1899 roku w Bobowej Krajowej Szkoły Koronkarskiej umiejętność wyrobu koronek klockowych na tym terenie była powszechnie znana. Przekazywanie tradycyjnych umiejętności rękodzielniczych w formie zorganizowanej $\mathrm{w}$ szkole, ma ogromne znaczenie dla rozwijania u szerokiego grona młodzieży cennych, wartościowo kształtujących osobowość działań.

\section{Technika wykonywania koronki klockowej}

Koronka klockowa - określenie to pochodzi od używanych do jej wyrobu drewnianych, wydłużonych szpulek, zakończonych trzonkiem, zwanym "klockiem". Koronka klockowa wykonywana jest przez splatanie ze sobą nici lnianych lub bawełnianych nawiniettych na specjalne szpulki zwane klockami. Kształt klocków bywa różny, często uwarunkowany grubością nici. Początkowo wyrabiano koronki $\mathrm{z}$ cienkich nici, które nie potrzebowały dużego obciążenia, klocki te były lekkie i niewielkich rozmiarów. Obecnie osiągają wielkość $14 \mathrm{~cm}$ długości, z czego $5 \mathrm{~cm}$ stanowi szpuleczka, a reszta to uchwyt. Kształt klocków przez lata zmieniał się, ale zawsze posiadał formę wydłużoną, pozwalając na umieszczenie dużej ilości klocków na niewielkiej przestrzeni. Klocki używane w Polsce najczęściej wyrabiane są $\mathrm{z}$ suchego drewna liściastego, często owocowego, ale także stosowało się klocki wyrabiane z kości lub tworzyw sztucznych. Piękne i obficie dekorowane - w przeciwieństwie do tych, pochodzących z kontynentu - to klocki pochodzące ze wschodnich Niderlandów, które bardzo, różnią się między sobą i rzadko kiedy spotkać można dwa identyczne.

Do ich wyrobu często używano drewna i kości, czasami nawet słoniowej, znane były także mosiężne, cynowe lub żelazne klocki, które były bardzo cienkie ze względu na ich ciężar. Robiono także klocki szklane, służące prawdopodobnie wyłącznie celom dekoracyjnym, jako że były zbyt kruche, by mogły być wykorzystane w praktyce. 


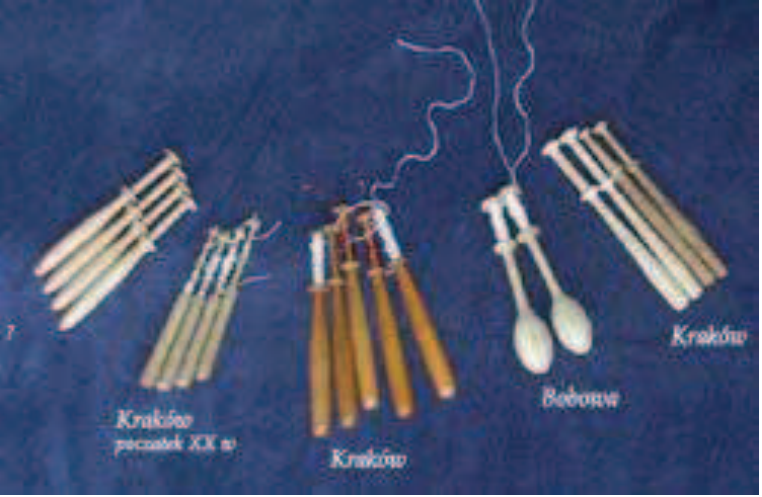

Fot. Bogusz G.

Klocki do wyrobu koronek są dodatkowo wyposażone w niewielkie kółko (najczęściej zrobione z koralików) służace do łączenia ze sobą większej ilości parek, żeby uniknąć plątania się nitek, co przy używaniu np. kilkudziesięciu parek nie jest bez znaczenia. Istnieją także klocki, w których nici są zabezpieczone przed zabrudzeniem specjalną tulejką nasuwaną na szpulkę. Przy robieniu koronek słowiańskich klocki trzymane są dłonią od spodu, często więcej niż jedna parka w dłoni.

Wzór koronki klockowej, narysowany na kalce technicznej i usztywniony od spodu tekturą, jest przypięty szpilkami do wałka wypchanego słomą lub trocinami. Wałek (w Bobowej zwany bębnem), to rodzaj podłużnej poduszki o przekroju koła, który umieszczamy na podstawce.

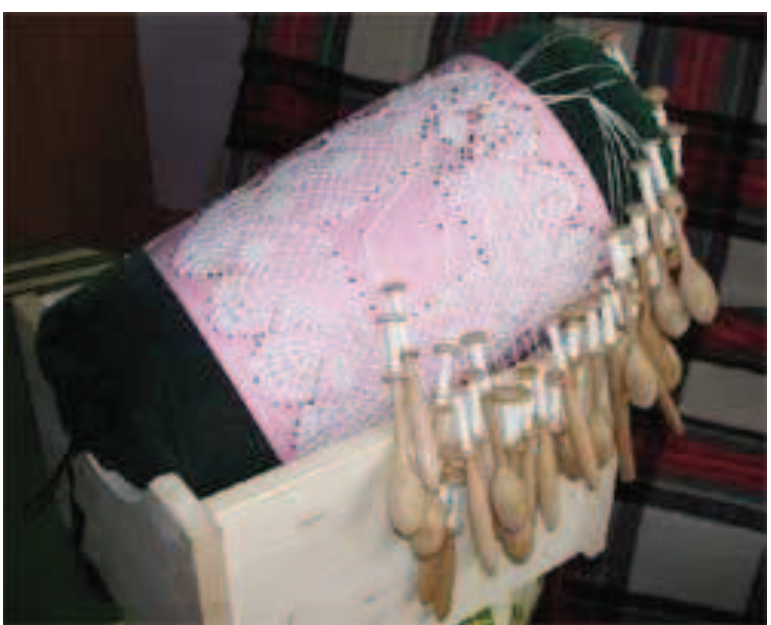

Zródło: Fotografia Bogusz G.

Istnieje wiele odmian koronek klockowych charakterystycznych dla różnych regionów świata, wyróżnia się jednak elementy, które występują w większości koronek Należą do nich listki (klasyczne lub kwadratowe), tasiemka (wykonana splotem tasiemkowym lub siekanką), ząbki w wielu odmianach, pikotki, łańcuszek,

kostki oraz charakterystyczne tło (baza wzoru) czyli siateczka/kratka.

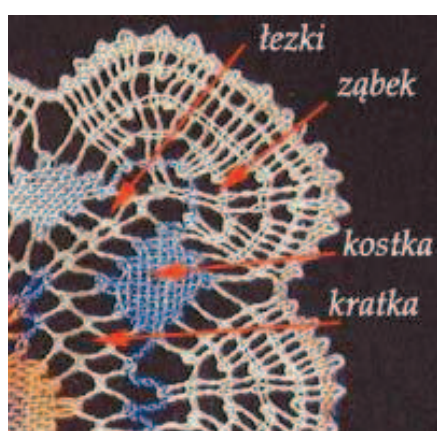

Zródło: Strony WWW:

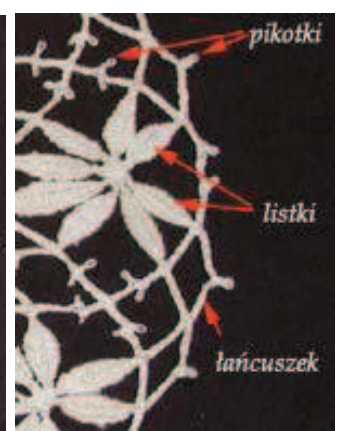

http://www.koronki.art.pl/

\section{Podstawowe sploty}

Dla poprawnego wykonania koronki istotne jest nawinięcie nici na klocki. Na rysunku pokazano kierunek nawijana nici.

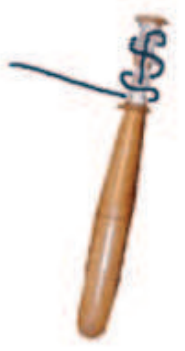

Kierunek nawijania nitki

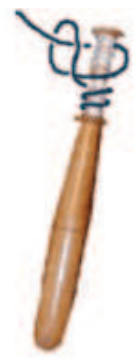

\section{Okręcanie}

Polega na przekładaniu prawej nitki nad lewą. Klocki okręcamy zawsze w lewą stronę.

\section{Krzyżowanie nitek}

Wykonuje się je odwrotnie niż okręcanie, czyli przekładając lewą nitkę nad prawą.

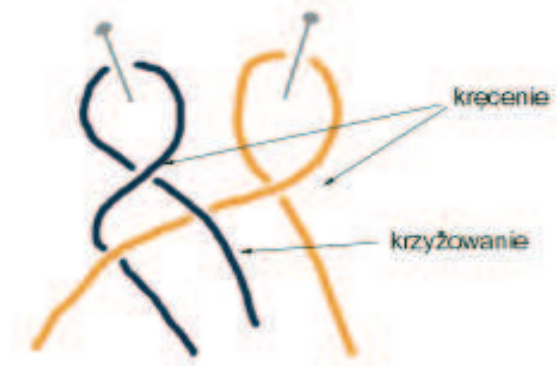

\section{Płócienko}

Polega na wymianie dwóch parek. Nitki przerabiamy w sposób analogiczny jak jest tkane płótno, czyli każda z nitek przechodzi raz górą a raz dołem. Najpierw krzyżujemy środkowe nitki (nitka lewa idzie górą), następnie okręcamy zewnętrzne nitki (w lewo) i znowu krzyżujemy wewnętrzne (lewa nitka górą). 


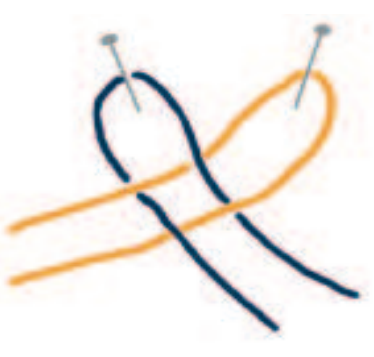

Lańcuszek (warkoczyk)

Wykonujemy go okręcając zewnętrzne nitki a następnie krzyżując wewnętrzne nitki.

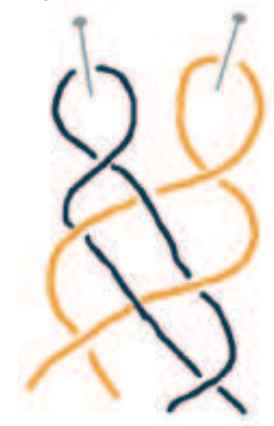

Tasiemka wykonana płócienkiem

Pomarańczowe nitki - to osnowa, a granatowa - to wątek, który zwany jest w koronkach klockowych parką przerabiającą. Parki zamieniamy ze sobą przy pomocy splotu płócienka, a na końcu okręcamy dwa razy parę przerabiającą, podtrzymujemy ją szpilką $\mathrm{i}$ w analogiczny sposób przerabiamy w drugą stronę ze wszystkimi parkami osnowy.

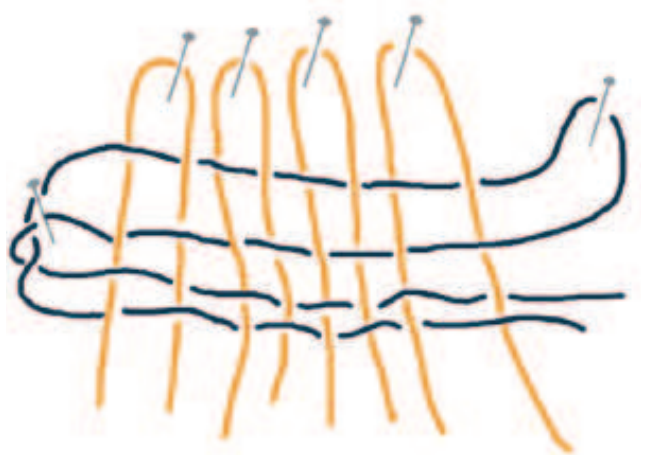

Listek

Całość listka wykonujemy używając dwóch parek klocków, jedna nitką przerabiającą, a jego kształt uzyskujemy poprzez odpowiednie wyciąganie nitek osnowy.

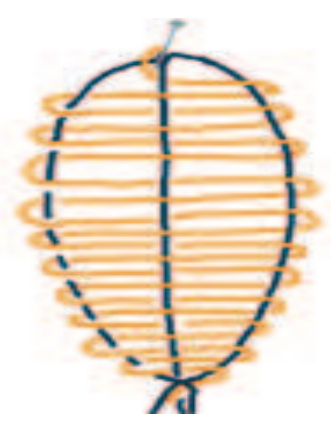

Koronka klockowa dzieli się na dwa podstawowe rodzaje, zwane również typami. Jest to koronka paskowa - nazywana słowiańską oraz koronka polska - nazywana potocznie czeską. Koronka paskowa powstała w XVIII wieku i wykształciła się $\mathrm{z}$ uproszczenia wzorów klockowych. Swoją nazwę zawdzięcza temu, że jej wzór stanowią różnej szerokości płócienkowe paseczki układające się we wzory. Typ koronki słowiańskiej wykonywany jest $\mathrm{w}$ wielu krajach Europy i każdy z nich wprowadza do niej własne motywy, które przyczyniają się do dużej różnorodności wzorów. W Polsce koronka paskowa cieszy się dużą popularnością, szczególnie na Śląsku i w Małopolsce. Znana z wyrobu tych koronek jest miejscowość Bobowa, która wprowadziła do nich nowe, regionalne motywy, wzbogacając ją tym samym w ciekawsze układy i skomplikowane wzory. Natomiast koronka polska pojawiła się na przełomie XIX i XX wieku w całej Europie. Powstała z połączenia niektórych elementów koronki gipiurowej, charakteryzującej się prostotą, z koronką słowiańską i dostosowała do potrzeb i najnowszych osiągnięć technologicznych. Jej najistotniejszą cechą jest pasmowość wzorów i geometryczność, choć bywają i motywy o bardzo uproszczonych formach roślinnych. Do tego typu koronek stosuje się nici o różnej grubości i barwie, a także płótno lniane, które wszywane jest w środek koronek.

\section{Ksztalty klasycznych koronek klockowych}

Najbardziej popularne kształty klasycznych koronek klockowych to koło, owal, kwadrat lub prostokąt, podłużna wstawka służąca do ozdabiania brzegów rękawów lub dołu spódnicy oraz ogromna gama kołnierzyków. Jeżeli chodzi o sztukę użytkową należy wymienić również zakładki do książek oraz trójkątne koronki stosowane do ozdabiania rogów obrusów lub pościeli. W nowoczesnej sztuce koronkarskiej nie ma praktycznie żadnych ograniczeń w kwestii formy, zastosowań czy też używanych 
materiałów. Kapelusze, bielizna, biżuteria (naszyjniki, kolczyki, bransoletki), obrazy czy też ozdoby choinkowe, wykonane techniką klockową są obecnie na porządku dziennym. To samo tyczy się nietypowych materiałów używanych do ich wykonania, takich jak drut miedziany (również posrebrzany i pozłacany), często $\mathrm{z}$ dodatkiem koralików lub nawet kamieni szlachetnych.

\section{Bobowska koronka to również element} stroju
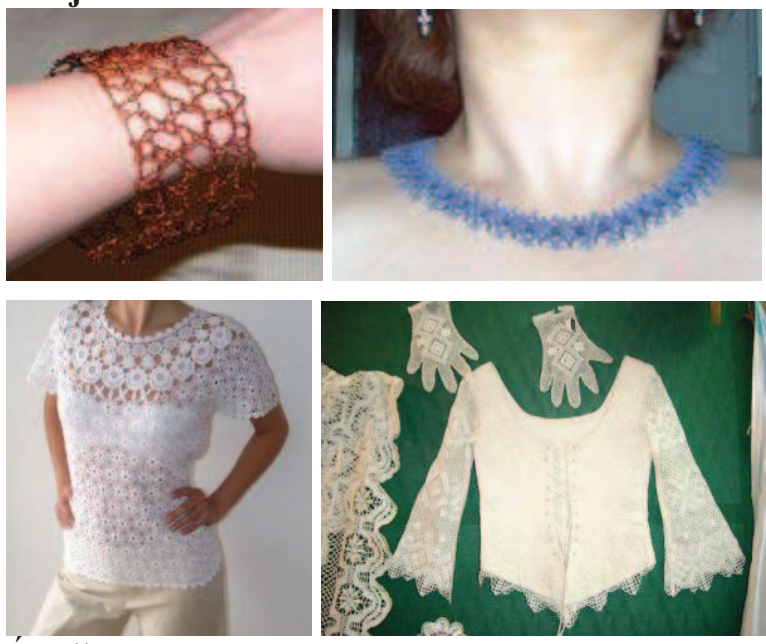

Źródło:

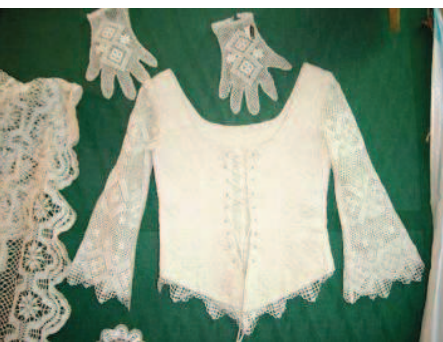

Strony

WWW:

http://www.koronki.art.pl/galerie

W klockowych koronkach wytwarzanych w Bobowej, bezsprzecznie zauważyć można charakterystyczne motywy regionalne, do których czerpane są wzory $\mathrm{z}$ natury. Są to przeważnie stylizowane, uproszczone kształty konkretnych roślin lub zwierząt (np. liście kasztanowca, dębu, astry, tulipany, ślimaki). W Bobowej przed laty wykonywało się najczęściej koronki klockowe zwane ogólnie polskimi (czeskimi) lecz z czasem zaczęto je zastępować słowiańskimi. Wprawna koronczarka może stworzyć rozmaite odmiany i warianty istniejących już wzorów koronek klockowych.

W koronce polskiej najczęściej stosowanym rodzajem splotu jest płócienko oraz splot sielankowy, który wykonuje się czasem w dwóch kolorach. Jej najbardziej charakterystyczną cechą jest tzw. pasmowość wzorów czyli całość zbudowana jest $\mathrm{z}$ dwóch lub trzech pasm koronki. Wzory typowe dla koronek klockowych, bobowskich bywają różne, często o bardzo uproszczonych formach zawierających motywy roślinne. W koronce polskiej stosują bobowskie koronczarki zestawienia różnorodnych nici. Są to więc połączenia nici grubszych $\mathrm{z}$ cienkimi, gładkich $\mathrm{z}$ posiadającymi szorstką fakturę. Najczęściej po wykonaniu koronki w jej środek wszywa się lniane płótno odpowiednio dobrane pod względem grubości i koloru. Natomiast w klockowej koronce słowiańskiej, dziś bardzo popularnej na terenie Bobowej, znaleźć można elementy zaczerpnięte $\mathrm{z}$ twórczości ludowej. Bardzo wyraźnie zaznacza się typowa tradycja rodzima odznaczająca się odmiennymi wzorami, których jest bardzo wiele, oraz skomplikowanymi układami taśm. Surowcem do wyrobu koronek najczęściej są nici lniane różnej grubości i koloru w zależności od przeznaczenia i wielkości danego wyrobu, np. z cienkich jasnych nici wykonuje się wstawki i narożniki do bielizny pościelowej. A $\mathrm{z}$ grubszych ciemniejszych bieżniki, serwety a nawet kapy. Oprócz typowych serwetek koronkowych wykonywano i wykonuje się do dnia dzisiejszego inne wyroby koronczarskie, takie jak: kamizelki, kołnierze i różne niewielkich wymiarów ozdoby.

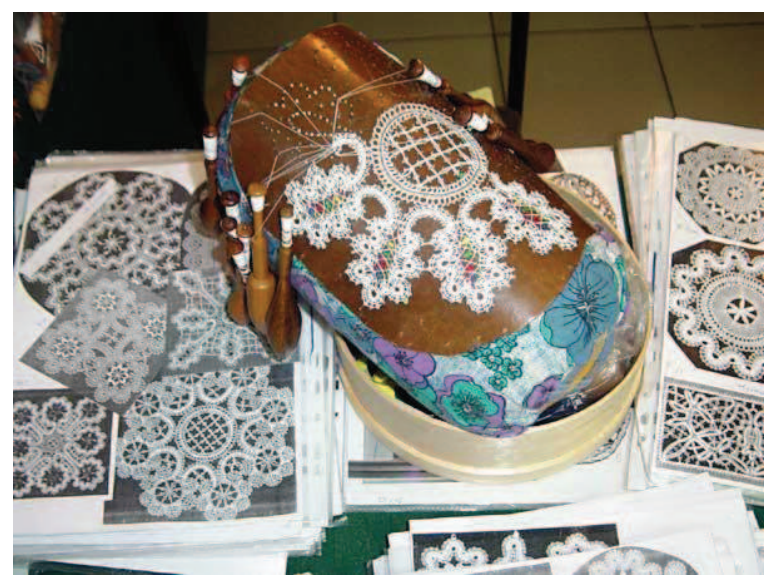

Źródło: Fotografia Bogusz G.

\section{Międzynarodowy Festiwal Koronki Klockowej}

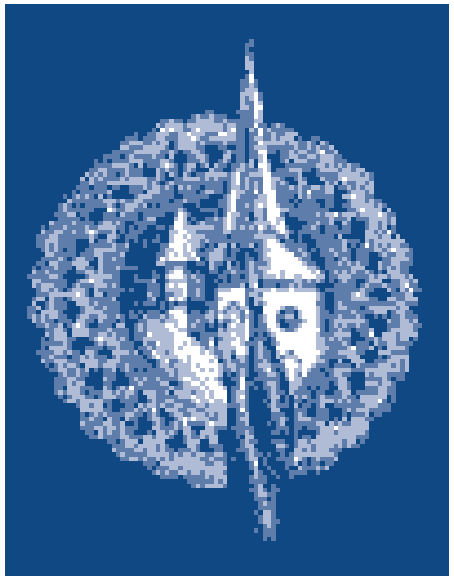

Logo festivalu 
Od roku 2000, na przełomie września i października organizowany jest w Bobowej Międzynarodowy Festiwal Koronki Klockowej. Pierwszy festiwal odbył się w dniach 1 - 8 października 2000 z udziałem ekip z Belgii, Włoch, Czech i Słowacji, a także oczywiście reprezentacji Bobowej i okolicznych gmin. Na 14 stoiskach koronkowe wyroby prezentowało 20 twórców. Festiwal i poprzedzające go kontakty międzynarodowe utwierdziła pośród bobowskich koronkarek przekonanie, że tworzą rękodzieło szczególnie cenione na zachodnich rynkach i że Bobowa jest w Polsce jedynym regionem skupiającym dużą grupę czynnych zawodowo twórczyń. W czasie trwania Festiwalu Koronki na stoiskach prezentowane były koronki z wielu państw europejskich zarówno nowe, jak też eksponaty muzealne.

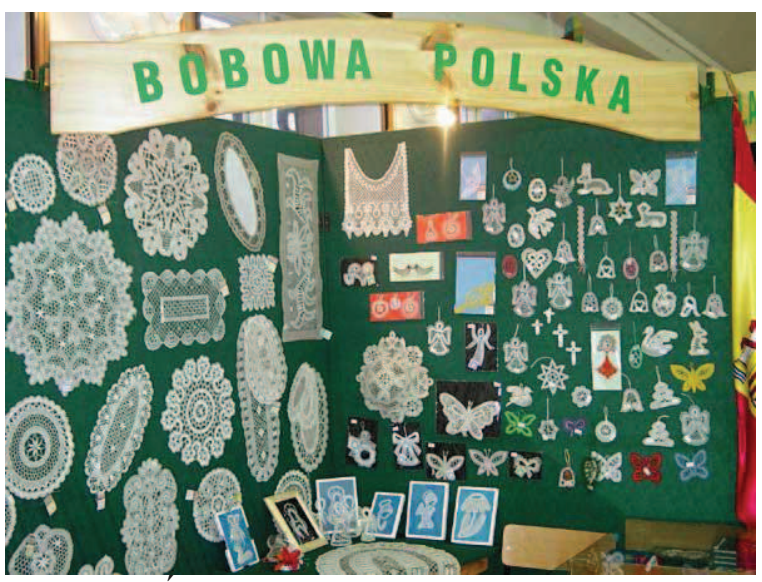

Zródło:Fotografia Bogusz G.

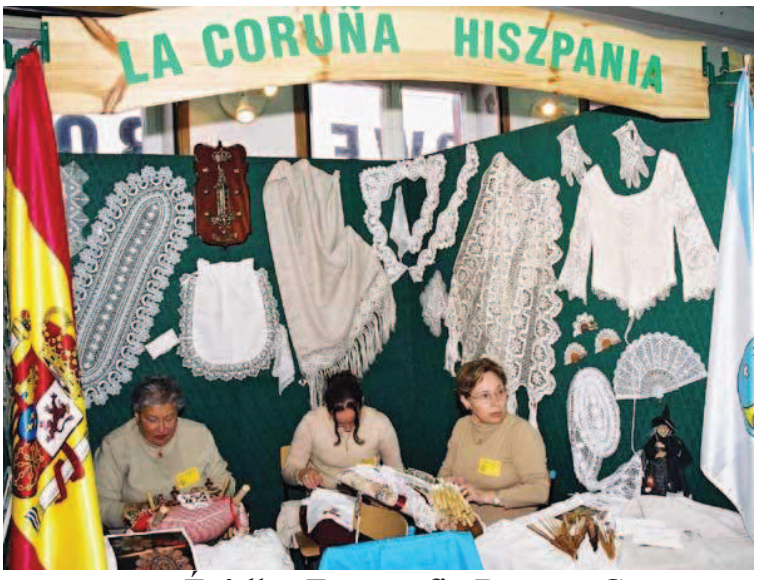

Zródło: Fotografia Bogusz G.

Koronka klockowa z Bobowej prezentowana jest także systematycznie na zagranicznych wystawach w Europie Zachodniej, jak również w Czechach i na Słowacji. Dzięki pomocy Ministerstwa Kultury i Dziedzictwa Narodowego oraz sponsorów, delegacje członkiń Stowarzyszenia Twórczości Regionalnej gościły np. trzykrotnie w Hiszpanii, dwukrotnie w Belgii i we Włoszech, a także odwiedziły Portugalię, Czechy i Słowację. Rezultatem tych wyjazdów było nawiązanie trwałych kontaktów, które zaowocowały ostatecznie zaproszeniem europejskich koronkarek na wielkie spotkanie do Bobowej.

\section{Zakończenie}

Wieś Bobowa rozsławiła się bogatym folklorem i pięknym rękodziełem ludowym. Najważniejsze jednak jest to, że szkoła podtrzymuje tradycje i wdraża młodzież do kultywowania tradycji koronkarskich. W ramach edukacji ogólnotechnicznej prowadzona jest nauka tej niełatwej sztuki, a także zajęcia dodatkowe dla bardziej zaawansowanych uczniów, które gwarantują rozwój zainteresowań technicznych. To właśnie szkoła jest w dużej mierze odpowiedzialna za rozwój zainteresowań uczniów na swoim terenie [E. Mastalerz, 2005r]. Prowadzone lekcje historii o tradycjach regionalnych są niewątpliwie kształcące, jednak praktyczne umiejętności wykonawstwa u młodzieży wyrobów znanych od pokoleń na tym terenie, nie tylko podtrzymują tradycje, ale rozwijają zręczność młodego człowieka. W wielu zawodach procentuje doskonale wyćwiczona zręczność manualna, koordynacja wzrokowo ruchowa, cierpliwość, zmysł estetyczny. Uświadomienie wartości pracy poprzez poznawanie tradycji, dorobku pracowitych twórców, doświadczania trudu działania praktycznego, rozwój umiejętności praktyczno technicznych jest możliwa także w oparciu o technikę koronki klockowej. Wykonywanie tego typu zadań technicznych stanowi okazję dla nauczyciela do zastosowania metody pokazu, projektowania działań, opracowania racjonalizacji działań poprzez wymyślanie oprzyrządowania, unowocześniania działań, praktycznego zorganizowania wykonawstwa w danych warunkach, współdziałania w grupie w celu sprawnego wykonywania splotów, planowanie różnorodnych zadań i ich prezentacji. Jest to także okazja do zastosowania różnego typu wizualizacji, w szczególności trudnych elementów (Tvaróżka W.) W rezultacie tak prowadzonego kształcenia młodzieży uzyskuje się rozwój kultury technicznej młodego człowieka, poszanowanie dla pracy i docenienie wysiłku osób $\mathrm{z}$ otoczenia, sprawne ręce i harmonijny rozwój osobowości, a więc spełnia się najważniejsze zadanie edukacji. 


\section{Bibliografia}

[1] KUBAL G., Bobowa w gminie i w okolicy, Wydawnictwo Roksana, Krosno 1999

[2] MAJCHER K., Bobowa historia, ludzie, zabytki. Bobowa 1991

[3] PISKORZ -BRANEKOVA E., Polskie hafty i koronki. Wydawnictwo Muza, Warszawa 2005

[4] RAJMAN J., Funkcje miast karpackich. Folia Geographica Vol. XV.

Materiały- foldery publikowane w celu promocji Międzynarodowego Festiwalu Koronki Klockowej, Bobowa 1983r.

[5] BOGUSZ G., Praca dyplomowa pod kierunkiem E. Mastalerz, Kraków 2006r.

[6] MASTALERZ E., O kształtowaniu zainteresowań technicznych młodzieży

[w:] Etyczny wymiar edukacji nauczycielskiej, praca zbiorowa pod red. A. Rumińskiego , Wydawnictwo Impuls, Kraków 2004.

[7] SERAFÍN, Č. Role elektrotechnických stavebnic $v$ obecně technickém vzdělávání. 1. vyd. Olomouc : VUP, 2005. ISBN 80-244-12314.

[8] NOGA H., Czy nowoczesność niweczy trud wychowania? [w:] Wychowawca 1998,nr 5, s.38-41. ISSN 1230-3720

[9] DOSTAL J., Rozvoj Celozivotniho vzdelavani ucitelu v oblasti vyuzivani pocitace ve vzdelavani [w:] Technika-Informatyka-Edukacja. Teoretyczne i praktyczne problemy edukacji informatycznej.Tom VIII. Rzeszów 2007, s.208212, ISBN 978-83-88845-94-9

[10] KRAUZ A., Instruktaż - proponowany model organizacji procesu praktycznego nauczania zawodu [w:] Technické vzdelávanie ako súčast' všeobecného vzdelávania, Univerzita Mateja Bela v Banska Bystrica, Velka Lomnica 2006. ISBN 80-8083-326-5, s. 21-22.

[11] SZOTKOWSKI, R. Zásada názornosti a počítačem podporovaná výuka. In Trendy ve vzdèláváni 2006, technika a informační technologie. Olomouc : PdF UPOL, 2006. ISBN 80-7220-260-X.

[12] TVARŮŽKA V.,Vizualni klip ve Vuce prymarni skoly [w:] Trendy ve vzdělávání informační technologie a technické vzdělávání „TVV 2010“mezinárodní vědecko odborná konferencje Deil I, Wydal: ALTYN s.r.o., Olomunc 2010, s.271-274, ISBN 978-80-8722409-0
Strony internetowe:

http://ck.bobowa.pl/koronki/

http://www.bobowa.pl/

http://www.flews.co.uk/

http://www.kantcentrum.com/

dr Elżbieta Mastalerz

Zakład Dydaktyki Przedmiotów Technicznych

i Informatycznych

Instytut Techniki, Uniwersytet Pedagogiczny

Kraków

E-mail: elzbietamastalerz@wp.pl 